\title{
The Nexus Between and Enhancement of Youth's Involvement in Agriculture: The Case of Eastern Region, Ghana
}

\author{
Bright Asiamah Korankye $^{1^{*}} \quad$ Lady Nadia Frempong $^{2} \quad$ Asare Isaac $^{1}$ \\ 1. School of Management Science and Economics, University of Electronic Science and Technology of China, \\ Chengdu, Sichuan Province, China \\ 2. School of Management, Sichuan Agricultural University, Chengdu, Sichuan Province, China
}

\begin{abstract}
This paper examines youth's involvement and the factors hindering youth's involvement in agriculture. The main objective is to access the engagement of Ghanaian youth in the Eastern Region in agriculture and the figure out factors hindering the youth's involvement in agriculture. The paper finds answers to the following questions; what really induce the youth to enter into agriculture? What conditions prevents youth from engaging in agriculture? Qualitative research techniques (interviews) were used. The choice model as well as the probit model was used in this paper. It was revealed that most of the youth engaged in agriculture are male as compared to female. Also, most of the youth are not interested in agriculture because of lack of credit facilities, limited startup capital, poor faming technology, use of primitive tools, soil degradation and limited farm lands. It was further revealed the youth migrate to the urban areas to search for job, good industries to work with, good social amenities, good education, and access to loans and enjoy high standard of living in the urban areas. Attention should be given to the factors leading to youth migrating to the urban areas. In addition, the limitations facing the youth in agriculture must be examined.
\end{abstract}

Keywords: Agriculture, Job choice, Migration, Unemployment, Youth.

DOI: $10.7176 / \mathrm{JBAH} / 9-10-03$

Publication date:May $31^{\text {st }} 2019$

\section{Introduction}

Agriculture is the cultivation of land and breeding of animals and plants to provide food , fiber, medicinal plants and other products to sustain and enhance life[1]. Agriculture in Ghana consists of a variety of agricultural products and is an established sector in Ghana. Agriculture provides employment on a formal and informal basis in Ghana and also produces a variety of crops in various climatic zones which range from dry savanna to wet forest which run in east west bands across the country[3] . Agricultural crops, including yams, grains, cocoa, oil palms, kola nuts, and timber, form the base of agriculture in Ghana's economy. In 2013 agriculture employed $53.6 \%$ of the total labor force in Ghana [4] and accounts for 40\% of Ghana's total GDP[5].

Youth on the other hand defined by the United Nations as all people between the ages of 15 and 24 represent approximately $60 \%$ of Ghana's population. As of today, the majority of the youth in Ghana live in urban areas as compared to those in the rural areas. This is because most of the youth see agriculture as inferior and belongs to the old and uneducated citizens[6]. Clearly, the way in which new generations will get involved in agriculture will influence the future of this sector in some years to come[7]. Despite Ghana's structural transformation, with growing income and expansion of the economy, it is likely that agriculture will continue to be the leading sector of employment for most young people over the next few years. Promoting participation of young people in agriculture and increasing their energy and innovation poses an opportunity for increasing agricultural productivity and decreasing poverty. There won't be expansion without youth. Young people have to be involved and finding how agriculture can be attractive for young people is a menace to most developing economies.

Ghana's agriculture is made up of few of the youth and more of the aging as a result there is small production unlike when the youth were to be vigorously involved in agriculture. Since majority of the youth are situated in the urban areas, there is too much pressure on the available jobs. Therefore a lot of people in order to earn a living engage in theft and robbery which threatens the citizens. Also because of most of the youth migrates to the urban areas, there is overcrowding, high unemployment rate, lack of accommodation in the urban areas whereas the rural areas continues to be under populated. This means that for Ghana to develop as a nation there is the need to put in place measures to enhance the youth's participation in agriculture particularly in the rural areas. This devastating menace contributed to the researcher's interest to research into the topic "enhancing youth's involvement in Agriculture in Ghana.

One of the major challenges faced by Ghana's youth is to find decent paying job. Although Ghana has experienced relatively high economic growth rates over the past years, formal job creation has been lower than the rate at which the labor force is growing. Challenges still remain on bridging the gap between economic growth and jobs creation and in turn address the growing unemployment especially among the youth.

Most of the youth in Ghana see agriculture belonging to the old and the illiterate. Little do they know that 
agriculture is a primary contributor of the nation's GDP. Most of the youth are migrating to the urban areas to search for jobs. Little do they know that most of the rich men in the urban areas have their farms in the rural areas which also fetch them some revenue. Many non-governmental organizations engage in agriculture and at the end of the day, it is profitable to them. The government has identified youth unemployment as a key challenge and taking steps to address it. [8] Point out that Africa has more people less than 25 years than above 50 years of age in all its countries. Ghana is no exception in this regard. The rural youth in agriculture are migrating to cities and towns with little success of finding decent jobs as they perceive instead, adding up to the already ever-growing unemployment in the urban areas. This raises questions such as: what restrains the youth from full engagement in the agricultural sector? is the government's efforts to enhance agricultural productivity going to be achieved? What will be the effects for Ghana's economy given the high growth rate of the population? Though youth employment issues are not fresh on the agendas of Ghana's policy, most agendas focused on nonagricultural and formal sectors as opportunities of job creation. Studies on youth engagement in agriculture on the Ghana front are small and most literatures are basically opinion centered and not empirically established.

In general, studies on Ghana and most developing countries' agriculture do reveal that the agricultural sector is for the uneducated[9]; and that farmers (uneducated) have low access to technologies, credit and extension services [10]. Yet this analysis is done at collective level and hides policy relevant information, therefore the main emphasis of this paper is on how to enhance youth engagement in the agricultural sector.

The main objective of this paper is to access the engagement of Ghanaian youth (Eastern Region) in agriculture and the factors hindering the youth's involvement in agriculture. The paper therefore seeks to find answers to the following questions; what really induce the youth to enter into agriculture? What conditions prevents youth from engaging in agriculture?

\section{Literature Review}

Existing literature reveals an old aged farming population in developing countries, with an average age of 47 years and life anticipation at 47-50 years in 2008 [11]. In 2000, Ghana's unemployment rate was as high as 10.40 percent and a record low of 2.20 percent in 2013, this is because some measures were put in place to make agriculture attractive to the people. Increased involvement of youth in agricultural activities will help reduce the problems of ageing farm population and also reduce youth unemployment [12]. This paper explores issues related to the enhancement of youth involvement in agriculture and factors hindering youth involvement in agriculture.

\subsection{Youth participation in agriculture}

Agriculture provides enormous employment opportunities for the youth, especially those in the Sub-Sahara Africa [13]. Numerous prospects exist along the line, from production to consumption. The youth is involved in producing agricultural crops (vegetables, food and cash crops), processing and preparing food, harvest and postharvest and storage activities, agriculture extension, teaching, working for wages in agricultural or other rural University enterprises, collecting fuel and water, engaging in trade and marketing, caring for family members and maintaining homes [13]. These agricultural employments can be classified as 'on the farm' and 'off the farm'. 'On the farm' agricultural embrace any agricultural activity conducted out of the home plot of land [13].[14] define 'off the farm' activities as the involvement of individuals in remunerative work away from a home plot of land. Any work carried out by the agricultural household other than working on their home plot of agricultural land is considered as off-farm acidities.

\subsection{Youth participation in non-agriculture}

[15] defines the labor market structures in typical developing countries as being divided into four main sectors: the formal sector (public and private), the informal sector (encompassing self-employment, informal sector wage labor, paid domestic workers, workers on monthly salary and casual workers), unpaid workers (individuals who work deprived of pay in an economic enterprise run by a related person) and the unemployed. The youth, though, lack experience and requisite employable skills hence mostly of the youth are found in the informal, unpaid and casual workers categories or are unemployed. In Ghana, the projected unemployment rate amid the youth aged 15 to 24 is $25.6 \%$; twice that of those between 25-44 years and three times of the 45-64 age group. [16]youth unemployment is always higher than adults globally because they are less experienced and have few skills to work. In addition, there is lack of information, networks and connections among the youth. Therefore the youth has no idea as to how to engage in agriculture.

\subsection{Efforts in enhancing youth engagement in agriculture}

[17] argues that the very high population growth need not be seen as liabilities but rather as assets for transforming the economy. The youth of every country is endowed with special abilities (dynamism, strength, adventure, ambition), these abilities are assets for agriculture [18]. Youth represents the most active part of every 
countries labor force and the device that do most productive work in the society [19]. The youth is also identified as the major resource base for any country that wishes to embark on any important agricultural and other developmental projects [20]. The youth are a formidable force in agricultural production process; the youth constitute a sizeable proportion of future progressive farmers and better citizens, especially in rural areas [21]. Therefore the youth present an opportunity for a sustained effort to participate in Ghana's development process because they have more energy, workforce and potential and have the capability to bring about a positive change. Stimulating growth of employment in the agricultural sector remains paramount in countries with a large agricultural sector, and improvements in agricultural productivity can generate more and better jobs in developing countries[22].

According to [23], Ghana's government is committed to encouraging value chain in agriculture. GBA further published that agriculture plays an important role towards Ghana's socioeconomic advancement, stressing that Ghana's agriculture has a giant potential; and that the government is devoted to assist the sector as part of the efforts to warrant food security and making agriculture good-looking to the youth. Ghana's government through the African Development Bank has initiated the Ghana Incentive-based Risk Sharing System for Agricultural Lending (GIRSAL) program, which is a risk mitigating tool that supports and encourages banks to lend more to the agricultural sector. Ghana's government is pushing forward its agenda to advance the agriculture sector through the implementation of the One Village, One Dam (1V1D) and the One District, One Factory (1D1F) flagship projects and this aims at enhancing the youth's engagement in agriculture for the advancement of the agricultural sector. Agricultural companies within the equipment and technology supporting and manufacturing industry to increase the production of the final product such as processing equipment, machinery and technology, finance and logistics, meat and meat related production, dairy-related products, animal feed production and confectionery products has come together to lay down policies help ensure the youths' engagement in agriculture.

Furthermore, Andrew Ahiaku, Head of Agribusiness, Barclays Bank of Ghana Limited, speaking with Ghana business news (GBN) also stated that Barclays bank is committed and passionate towards Ghana's agricultural sector. He said "agriculture contributed enormously to Ghana's gross domestic products (GDP); stating that "and for us as a bank, this quantum is too important to ignore, that is why we are one of the few banks that have a dedicated desk towards agriculture finance, not only agri-finance but agribusiness finance, because we see agriculture as a value chain approach. Since 2014 the Bank, had advanced \$65million to their clients in the maize, rice and soya value chain alone, not to talk about cocoa and other subsectors".

According to [24,25] the youth's choice to travel includes "push" and "pull" factors. The "push factors' include decreasing national resources; increasing cost of social amenities; loss of employment, oppressive religious, ethnic or political concerns; alienation from community; lack of opportunities for personal development, and/or effect of natural disaster. The 'pull factors' are the possibility of improved employment opportunities; good educational facilities; diversified marriage opportunities, and enhanced recreational activities. [26]. However, [27] points out that some empirical studies see economic push factors (such as, the lack of rural credit, unemployment, and rural poverty among others) are most important; while economic pull factors (such as, perception of high wages from urban employment) are dominant. This assertion can be used to explain why there is a diminishing involvement of the youth in agriculture in Ghana.

Migration is a transfer of labor from labor-surplus sectors (rural areas) to labor deficit-sectors (urban areas) until a balance is reached according to the Lewis model[28]. The Harris-Todaro model also proposes that travelers assess numerous labor market opportunities available in the rural and urban areas and select the one that maximizes their projected gains. This model explains some of the shortages in the Lewis model including the growth in rural-urban migration in the setting of increasing urban unemployment. Some empirical readings establish the fact that economic push factors (the lack of rural credit, rural poverty, unemployment) are most important; others also advocate that economic pull factors (perception of high wages from urban employment) are prevailing[29].

Despite incentives and other programs put in place to expand markets for primary and secondary agricultural commodities, the involvement of the youth in agricultural activities has steadily declined in recent years[30]. Although there are numerous studies in the field of agriculture relating to youth's involvement, most of the studies were conducted in a different aspect of Agriculture and few studies focuses on how to involve the youth in agriculture.

[31] conducted a study on the youth engagement in agriculture and it was revealed that most of the youth do not engage in agriculture because they have the notion that Agriculture is for the less educated; lack of credit facilities; the physical nature of agriculture. Although this works gives a meaningful result, the study took place in outside Ghana but this work is focused in Ghana. [10], also conducted a study on youth in agriculture in Malawi. Their study showed that youth in agriculture have little or no direct interactions with each other. Therefore, youth remain on the periphery of agricultural policymaking and their role in shaping agricultural policy dialogue is negligible. They did not place emphasis on how to engage the youth in agriculture itself but 
rather how to involve the youth in agricultural policy making process. Also the study was carried in Malawi and this paper is focused on Ghanaian youth.

Furthermore, [30] conducted a study on the roles of Nigerian youth in food production in Nigeria. In their study they looked at the reasons why the youth is not actively involved in agriculture. Structured interview schedule was conducted on the respondents to elicit data. Descriptive statistics (Mean, frequency, and percentages) were used to analyze the data collected. Thirty (30) youths were selected from three (3) districts (Biraidu, Okura, and Dekina) through simple random sampling thus making a total of 90 respondents. The results showed that aged parents were the major producers of food crops, and cassava was the major staple food produced in the area. Credit facilities should be provided to youths engaged in agriculture to serve as a motivating factor for them to remain in agriculture and also to attract more youth. There is a research gap because their work used 90 respondents but this work uses 100 respondents also their work focused on the Nigerian youth but this work focuses on Ghanaian youth.

This work uses some of these findings to help explain the extent of youth's involvement in agriculture in Ghana.

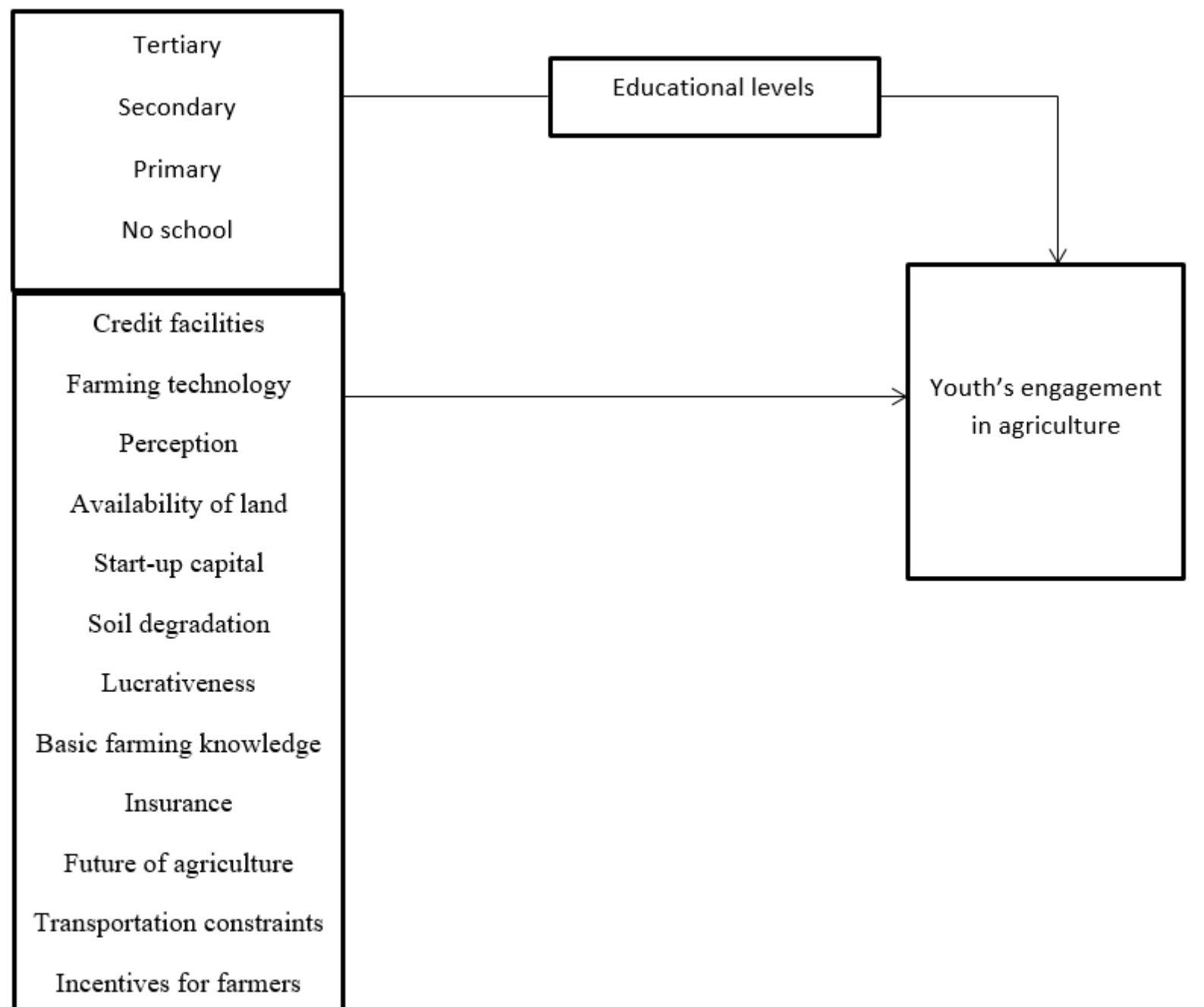

Figure 1. Conceptual framework

Consent of parents

\section{Materials and Methods}

The paper is based on literature review and structured interviews with youth and public institutions associated with youth employment and development to validate the finding from the literature. Qualitative research techniques were used because of the nature of respondents (educated and uneducated) in order to explore their opinions on enhancing youth's involvement in agriculture. Interview makes it easier for respondent to express 
their views and ask probing question, since this research deals with opinions and some of the respondents cannot read and write, it proves it necessary to use interview as the source of collecting data. Structured interview was used this means that, series of pre-determined questions were set and all interviewees answer in the same order. This enhanced data analysis to be more straightforward. [32]. The study was carried out in the Eastern region of Ghana. The Eastern region has (26) districts. Out of the 26 districts, 8 districts were selected for the study using the purposive sampling technique. The respondents consist of four hundred male and female selected from rural and urban areas in the Eastern region of Ghana.

Table 1: Sample selection

\begin{tabular}{|l|l|}
\hline Districts & Number of respondents \\
\hline Birim Central Municipal District, & 50 \\
\hline Birim South & 50 \\
\hline Akyemansa, Ofoase & 50 \\
\hline Birim North, New Abirem & 50 \\
\hline Akuapim North Municipal, Akropong & 50 \\
\hline Kwaebibirem, Kade & 50 \\
\hline Kwahu East & 50 \\
\hline Fanteakwa, Begoro & 50 \\
\hline
\end{tabular}

Source: Field survey, 2019

Data collected from the field through the use of well-structured questionnaire were subjected to analysis using the frequency of occurrence, percentage of occurrence and the mean of the population. In other to empirically test the hypothesis of the study, the chi-square was employed.

The choice model can be used to determine whether the youth is willing to engage in agriculture or not. The choice model has its root in the utility theory. Choice models can be used to forecast with high accuracy on how individuals will behave in a given situation [33]. Random utility theory assumes that the utility an individual derives from a choice piece can be divided into a systematic component and random idiosyncratic component. The systematic component captures the characteristics of the choice substitutes and the features of the individual, [33]. Choice models as proposed by [34] is thought to be the most precise and general purpose tool presently accessible for predicting human decision making behavior [33]. The choice model allows individuals to identify the kind of sample covariance matrix, particularly for the choice models [33].

Nevertheless, the binary choices must be converted using threshold models, with the converted data analyzed with the available standard structural equation modeling software [33]. [35] used this to derive the logit model to represent discrete choice [33]. Discrete Choice Modeling analyses the choice behavior of individuals and groups who are faced with discrete economic alternatives [33].

Utility theory, conversely, is concerned with an individual's choices, decisions and preferences as well as individual's judgments of worth, value, goodness, perception or/and any alike concepts [35]. Qualitative response models are strongly linked to utility theory and have been broadly used in economics to investigate factors affecting an individual's preference from among two or more substitutes [36]. Models for assessing dichotomous choices in which the dependent variable is binary also has its root in the threshold theory of decision-making in which a reaction occurs only after the power of an incentive increases beyond the individual's reaction threshold[37,33]. The theory postulates when individuals are confronted with the choice to accept or not accept an invention, every individual has a response edge, which is determined by certain factors [27]. Thus, at a certain value of impetus below the edge, no involvement will occurs whilst at the particular threshold value, a reaction is stimulated[27]. Such phenomena are generally modeled using the relationship:

$$
\mathrm{Yi}=\beta \mathrm{Xi}+\mathrm{U}
$$

Where $\mathrm{Yi}=1$, when a choice is made and 0 , otherwise. This means

$$
\begin{aligned}
& \mathrm{Yi}=1 \text { if } \mathrm{Xi} \geq \mathrm{X}^{*} \\
& \mathrm{Yi}=0 \text { if } \mathrm{Xi} \leq \mathrm{X}^{*}
\end{aligned}
$$

$\mathrm{X}^{*}$ represents the joint effects of explanatory variables ( $\left.\beta \mathrm{iXi}\right)$ at the threshold level.

The model is a binary choice model concerning estimation of the likelihood of adoption of a given phenomenon $(\mathrm{Y})$ as a function of explanatory variable $(\mathrm{X})$. That is;

$$
\begin{aligned}
& \operatorname{Prob}(Y=1)=F\left(\beta^{\prime} X\right) \\
& \operatorname{Prob}(Y=0)=1-F\left(\beta^{\prime} X\right)
\end{aligned}
$$

This implies that every youth in the Ghana also has a reaction edge which is dependent on a set of factors. The individual youth either participates in the agriculture or not. This produces a binary dependent variable, "Yi" which takes on the value 0 (for not participating in agriculture) and 1 (for participating in agriculture) and $\mathrm{Xi}$ is a set of explanatory variables. The youth are concerned with the utility they will obtain from participating in agriculture.

In this paper, we also used the probit model to examine factors that are likely to influence the decision of youth 
to or not to engage in agriculture.

$$
\mathrm{P}\left(\mathrm{Y}_{\mathrm{i}}=1 / \mathrm{X}_{\mathrm{i}}\right)=\mathrm{Z}\left(\alpha+\beta_{\mathrm{i}} \mathrm{X}_{\mathrm{i}}+\varepsilon_{\mathrm{i}}\right)
$$

When the function takes on a linear form, it is referred as a linear probability model (LPM). According to (Wooldridge, 2009), LPM could be appropriate for capturing the expected values of youth engagement in Agriculture but it has two adverse effects these are: producing predicted probabilities that are less than zero or greater than one, and constant partial effects of the explanatory variables appearing in their original form. To ensure that the explanatory variables are between zero (0) and one (1), the function in equation (1) above is either normally distributed for the probit model.

$\mathrm{Y}=1$ if the youth is engaged in agriculture as the main sector of employment and $p_{\mathrm{i}}$ is the probability that the $i^{\text {th }}$ youth engages in agriculture. The explanatory variables that include individual youth characteristics are represented by $X_{i}$. The parameters to be estimated in equation (1) are $\alpha$ and $\beta$. The error term ${ }^{\text {eici }}$ is included in the equation to take care of any other factors that might have not been included in the model but may influence youth to get engaged or not to get engaged in agriculture as the primary source of employment.

The explanatory variables in equation (1) are individual characteristics; educational characteristics and gender (both in rural and urban areas). Monthly income of farmers, other variables included location and region. Based on the above factors, it can be proposed that a youth make the most of his/her welfare by making a select between agriculture and the other sectors of the economy.

The paper is based on the following hypothesis: 1 . Higher education has inverse relationship with interest in agriculture. 2. There is no significant relationship between factors militating against youth and their involvement in agricultural production. 3. There is significant relationship between factors militating against youth and their involvement in agricultural production.

\section{Results and Discussions}

Table 2. Socio-economic characteristics

\begin{tabular}{|l|l|l|}
\hline Gender & Rural areas & Urban areas \\
\hline Male & 112 & 104 \\
\hline Female & 88 & 96 \\
\hline
\end{tabular}

Survey 2019

According to table 2, majority of the respondents are male both in the rural and urban areas with minority being female this gives an indication that, the findings are more of male views than female. Studying table 2 carefully, it can be seen that the difference between males and females in the rural areas are more than the difference between male and females in the urban areas. The difference arises largely because in the urban areas there are more improved methods of farming so the females can engage well in agriculture but in the rural areas, the method of farming is more primitive.

Table 3. Youth in the rural areas engaged/not engaged in agriculture

\begin{tabular}{|l|l|l|}
\hline Gender & Engaged & Not engaged \\
\hline Male & 77 & 35 \\
\hline Female & 48 & 40 \\
\hline
\end{tabular}

Survey 2019

Table 3 depicts most of the youth in the rural areas are engaged in agriculture with 52 male youth leading as compared to 23 female youth. This disparity may be as a result of the fact that, agriculture in Ghana requires more of the physical strength. This finding confirms the work of [30] who found that majority of the youth residing in the rural areas are engaged in agricultural activities, with males dominating.

Table 4. Youth in the urban areas engaged/not engaged in agriculture

\begin{tabular}{|l|l|l|}
\hline Gender & Engaged & Not engaged \\
\hline Male & 37 & 67 \\
\hline Female & 33 & 63 \\
\hline
\end{tabular}

Survey 2019

Table 4 clearly shows that, minority of the youth in the urban areas are engaged in agriculture. This is due to the fact that most of the youth in the urban areas have upgraded themselves in education and found other jobs which fetch them more income as compared to agriculture. These factors have been identified primarily through surveys [30]. From the literature review, there are economic, social and environmental factors reducing rural youth involvement in agricultural production in Ghana. These factors include inadequate credit facilities, low startup capital, production inputs and bad perception about agriculture. 
Table 5. Educational characteristics

\begin{tabular}{|l|l|l|}
\hline Levels & Rural areas & Urban areas \\
\hline Secondary school & 48 & 70 \\
\hline Primary school & 60 & 50 \\
\hline No school & 50 & 46 \\
\hline Tertiary & 42 & 34 \\
\hline
\end{tabular}

\section{Survey 2019}

The results also indicate that urban youth obtain a higher level of education, with 70 respondents of urban youths achieving the level of a secondary school education, compared to 48 of rural youth (table 5) because there are good educational facilities in the urban areas as compared to the rural areas. Table 5 further shows that the higher the level of education, the lower the interest to engage in agriculture. This may highly be due to the perception that, agriculture belongs to the little and non-educated elites. Therefore hypothesis 1 will be accepted.

Table 6. Monthly income of youth engaged in agriculture in Ghana cedis

\begin{tabular}{|l|l|l|}
\hline Income & Rural areas & Urban areas \\
\hline Below 200 cedis & 114 & 83 \\
\hline Between 200 to 500 cedis & 45 & 68 \\
\hline Above 500 cedis & 41 & 49 \\
\hline
\end{tabular}

Survey 2019

With respect to table 6, majority of the youth living in the rural areas earn below 200 cedis every month[38]. Most of these people have families to cater for, so therefore earning below 200 cedis every month is below the belt to sustain them and their families. They therefore migrate to the urban areas to search for higher paying jobs [39].

Table 7. Factors preventing youth involvement in agriculture in Ghana (in percentages)

\begin{tabular}{|l|l|l|}
\hline Factors $\{$ Olayiwola (2005)\} & Percentages (\%) & Ranking \\
\hline Lack of credit facilities & 97 & 1 \\
\hline Poor faming technology & 92 & 2 \\
\hline Use of primitive tools & 87 & 3 \\
\hline Bad perception about agriculture & 81 & 4 \\
\hline Limited farm lands & 60 & 6 \\
\hline Soil degradation & 76 & 5 \\
\hline Limited startup capital & 97 & 1 \\
\hline
\end{tabular}

\section{Survey 2019}

According to table 7, majority of the youth are not involved in agriculture because of Lack of credit facilities, limited startup capital, poor farming technology and the use of primitive tools in agriculture. This is line with the work of $[10,40]$, who also stated that factors preventing youth involvement in agriculture are Lack of credit facilities, Poor faming technology, Use of primitive tools and bad perception about agriculture. These findings were consistent with the opinion of the youth leaders interviewed by the author.

Table 8. Chi-square test of the relationship level of youth's participation in agriculture.

\begin{tabular}{|l|l|l|l|}
\hline Factors & Chi-square & Probability & Decision \\
\hline Lack of credit facilities & 1.69 & 0.00 & suitable \\
\hline Returns on investment & 0.19 & 0.65 & Not suitable \\
\hline Use of primitive tools & 1.37 & 0.00 & Suitable \\
\hline Bad perception about agriculture & 2.51 & 0.00 & suitable \\
\hline Limited farm lands & 7.48 & 0.00 & Suitable \\
\hline Soil degradation & 1.34 & 0.00 & suitable \\
\hline Limited startup capital & 1.48 & 0.00 & suitable \\
\hline lucrativeness & 7.12 & 0.00 & suitable \\
\hline Poor faming technology & 1.89 & 0.00 & suitable \\
\hline Basic farming knowledge & 1.71 & 0.00 & suitable \\
\hline Insurance & 4.93 & 0.00 & suitable \\
\hline Future of agriculture & 2.86 & 0.00 & suitable \\
\hline Transportation constraints & 1.06 & 0.00 & suitable \\
\hline Incentives for farmers & 1.26 & 0.00 & suitable \\
\hline Available market & 2.82 & 0.00 & suitable \\
\hline Consent of parents & 0.25 & 0.93 & Not suitable \\
\hline Significancever & & \\
\hline
\end{tabular}

Significance level $=0.05$

Survey, 2019 
Table 8 reveals that at 0.05 level of significance, nearly all the variables had significant relationship with level of participation in agricultural activities among (youth) respondents. Undeniably, only two (returns on investment and consent of parents) out of the sixteen variables were not significantly related to the levels of participation in farming among (youth) respondents. Consent of parents was not a significant variable perhaps due non-interference by parents of respondents on the participation in agriculture amongst their wards. Likewise, the non-significance of 'returns on investment as a perceived constraint to respondents' level of participation in farming activities might be due to relative ignorance of returns on investment in the study area. However, the significance relationship between level of participation in agricultural production and the other listed variables suggests that the level of participation in agriculture among youths in the study area is still beleaguered with a lot of variables. Table 8 further summarizes the results of the chi-square analysis used to test the stated hypothesis, which was to determine whether or not there were significant differences in the perceived constraints and participation in agricultural among the respondents.

Table 9. Factors accounting for rural youth migrating to urban areas

\begin{tabular}{|l|l|l|}
\hline Factors $\{$ Echebiri (2005)\} & Percentages (\%) & Ranking \\
\hline Search for decent job & 98 & 1 \\
\hline Poor education in the rural areas & 96 & 2 \\
\hline To find marriage partner & 42 & 7 \\
\hline To join family members & 12 & 8 \\
\hline Doesn't like village life & 57 & 6 \\
\hline Low standard of living in the rural areas & 84 & 5 \\
\hline No industries in the rural areas & 96 & 2 \\
\hline Poor social amenities in the rural areas & 88 & 4 \\
\hline To get access to loans & 95 & 3 \\
\hline Survey 2019 &
\end{tabular}

Survey 2019

Table 9 shows that, the youth in the rural areas migrates the urban areas largely because of indecent jobs in the rural areas. Some of the respondents also said that they migrate to the urban areas because to search for good education and work in industries in the urban areas. Few of the youth migrate to the urban areas mainly to join their families and also to find marriage partners. This finding is in accordance to the findings of [40] who identified factors affecting youth rural-urban migration. He pointed out factors including, poor physical infrastructure and social amenities in the rural areas, search for education and skills acquisition, and the absence of desirable job opportunities. The results further confirmed that, regardless of the difficulties in finding employment, a majority of rural youths preferred living in urban areas. The findings are also consistent with the findings of $[41,42]$ who found that rural areas in Nigeria were neglected with respect to the provision of social and economic opportunities.

\section{Conclusion}

It can be concluded that, youth in Ghana forms the majority of the active labor force in Ghana. Agriculture plays an important role when it comes to the GDP of Ghana. Most of the youth engaged in agriculture are males with female being the minority. It was clearly seen that, the government of Ghana has put measures in place to enhance the youth's engagement in agriculture (one district one factory, one village one dam). Banks and other financial institutions are also playing their role in enhancing youth's engagement in agriculture by providing credit facilities. It was also revealed that most of the youth are not interested in agriculture because of lack of credit facilities, limited startup capital, poor faming technology, use of primitive tools, bad perception about agriculture, soil degradation and limited farm lands. The youth also leave the rural areas for the urban areas to search for decent job, no industries in the rural areas, poor social amenities in the rural areas, poor education in the rural areas, to get access to loans and low standard of living in the rural areas

The results derived from the literature and substantiated by interviews of the respondents confirm that, the push and pull factors affect youth's migrating to the urban areas. In order to enhance youth's engagement in agriculture in Ghana, attention should be given to the factors leading to youth migrating to the urban areas. In addition, the limitations facing the youth in agriculture (lack of credit facilities, limited startup capital, poor faming technology, use of primitive tools, bad perception about agriculture, soil degradation and limited farm lands, etc.) must be examined.

In view of the research results, Ghana is likely to be confronted with an uneducated and ageing farming population sooner than later if the current limitations encountered by the youth in agriculture are not tackled and most of the schools in the rural areas and urban areas should place prior emphasis on the importance of agriculture. Furthermore, with laid down measures, the youth can still be at the lead of stimulating the agricultural sector. This could make the sector a likely source of lucrative employment for the gigantic unemployed and under-employed youth. 
Also there is the urgent need for the Ghanaian government, in consultation with all pertinent stakeholders, not neglecting the youth, to come out with a policy that guarantees the enhancement of the youth in various agricultural sector programs and policies. Such a policy can simply be active if the youth are made to engage with policy makers. This requires that government in conjunction with the private sector should invest in enhancing the capability of the youth, either as persons or as youth organizations, to coordinate with productive organizations to help provide funds and other inputs to enhance youth's engagement in agriculture.

\section{References}

[1] Food and Agriculture Organization and World Bank, "Agricultural land (\% of land area). Open license Data," World Bank databank, $2016 . \quad$ Available online: https://data.worldbank.org/indicator/AG.LND.AGRI.ZS.

[2] Wood, E.; Tappan, G.; Hadj, 2004. Understanding the drivers of agricultural land use change in southcentral Senegal. Ambio, vol. 41, no. 7, pp. 738-750,.

[3] Adofu, I.; Abula, M.; Audu, S.I. (2010). An Assessment of the Effects of Interest Rate Deregulation in Enhancing Agricultural Productivity in Nigeria. Current Research Journal of Economic Theory, 2(2). $82-86$

[4] Dixon, R. B. (1982). Women in Agriculture: Counting the Labor Force in Developing Countries. Population and Development Review, 8(3),

[5] Breisinger, X.; Diao, J. Thurlow.; Al-Hassan R. M. (2008). "Agriculture for Development in Ghana : New Opportunities and Challenges," System, no. 15, p. 4.

[6] Nweke, A. (2002). "Adoption behavior of Farmers towards yam mini sets technology in Imo State Nigeria" A paper presented at the 25th annual conference of Agricultural Science Society of Nigeria. Federal University of Technology Oweri, 5-6th September 1989. Pg 18-21.

[7] Jericho G., (2013) "Australia is changing - where will future productivity growth come from?," The Guardian,.

[8] Kararach G.; Kobena T. H., Frannie A.L (2011), Regional Integration Policies to Support Job Creation for Africa's Burgeoning Youth Population.

[9] Food and Agriculture Organization, The State of Food and Agriculture. Women in Agriculture: Closing the Gap for Development, vol. 2. 2011.

[10] Olayiwola, O. F., (2005). Perception of rural- urban migration in selected rural communities in Ondo state, Nigeria. A publication from department of sociology, Adekunle Ajasin University AKungba,

[11] Wooldridge, M. (2009). An Introduction to MultiAgent Systems - Second Edition. 2nd Edition. John Wiley \& Sons.

[12] Moya, S. (2018) “Ghana GDP Annual Growth Rate | 2000-2018,” C2018 TRADING ECONOMICS,. [Online]. Available: https://tradingeconomics.com/ghana/gdp-growth-annual.

[13] Bosompem, M.; Acheampong, E.; Osei, M. K. (2011). Young and Proudly Agriculturalist, G. E. A. paper presented at a workshop on "Opportunities in A. and R. A. for Y. in times of N. I. T. A. Y. A.

[14] Abdul-Hakim; Che-Mat (2011). Determinants of Farmeres Participation in Off-Farm Employment: A Case Study in Kedah Darul-Aman, Malaysia, Asian Journal of Agricultural and rural Development, 1 (2).

[15] Wambui, R. W., (2010). Determinants of Employment in the Formal and Informal Sectors of the Urban Areas of Kenya. p 45.

[16] Manpower Group (2012) Youth Unemployment, Challenges and Solutions: What Businesses Can Do. Retrieved on 27th June, 2013.

[17] Jong-Dae P. (2012), Uganda's Rural Transformation lies in Community - Based Agriculture. Rural Development, Daily Monitor. Monday, June 18.

[18] Nnadi F.N.; Akwiwu, C.D., (2008), "Determinants of Youths' Participation in Rural Agriculture in Imo State, Nigeria", Journal of Applied Sciences.

[19] Adesope, O.M. (1996), Evaluation of Youths Participation in Community Development Projects in River State, Nigeria. Unpublished M.Sc. Thesis, Department of Agricultural Economics and Extension, Federal University of Technology.

[20] Onuekwusi, G. C. (2005), "Youth Programme in Extension and Rural Development", in: Nwachukwu and Onuekwusi, G.C. (eds). Agricultural Extension and Rural Sociology. Snaap Press.

[21] Aphunu, A.; C.N. Atoma (2010), "Rural Youths' Involvement in Agricultural Production in Delta Central Agricultural Zone: Challenge to Agricultural Extension Development in Delta State", Journal of Agricultural Extension.

[22] World Bank (2008), Agriculture for Development.

[23] Ghana Business News (GBN).

[24] Lewis, W., 1954. Economic development with unlimited supplies of labour. The Manchester school, vol. 


\section{2, no. 2 .}

[25] Harris, J. R.; Todaro, M. P. (1970). "Migration, unemployment and development: A two sector analysis. AmericanEconomic Review.

[26] Bogue, D., 1996. Principles of Demography, Wiley.

[27] Akudugu, M. A. (2012). Estimation of the Determinants of Credit Demand by Farmers and Supply by Rural Banks in Ghana's Upper East Region, Asian Journal of Agriculture and Rural Development, 2 (2),

[28] Figueroa, M. "W. Arthur Lewis versus the Lewis model: Agricultural or industrial development?," Manchester School, vol. 72, no. 6. pp. 736-750, 2004.

[29] Kimaro, P. J.(2015) "Determinants of Rural Youth's Participation in Agricultural Activities : the Case of Kahe East Ward in Moshi Rural District, Tanzania," Int. J. Econ. Commer. Manag., vol. III, no. 2, pp. $1-47,2015$.

[30] Adekunle O.A.; Adefalu, L.L.; F.O., Oladipo, R.S. Adisa, Fatoye, A.D. (2009), "Constraints to youth involvement in agricultural production in kwara state, Nigeria”, Journal of agricultural extension.

[31] Kimaro, P. J. (2015). Determinants of Rural Youth' S Participation in Agricultural Activities : the Case of Kahe East Ward in Moshi Rural District, Tanzania. International Journal of Economics, Commerce and Management, III(2).

[32] Boyce, C.; Neale, P. (2006) "Conducting in-depth Interviews: A Guide for Designing and Conducting In-Depth Interviews."

[33] Rungie, C.; Coote, L.V.; Louviere, J. J. (2011). Structural choice modelling: theory and applications to combining choice experiments. Journal of Choice Modelling, 4(3),

[34] Maydeu-Olivares, A.; Böckenholt, O. (2005). Structural equation modelling of paired comparison and ranking data. Psychological methods, 10.

[35] McFadden, D. (2012). The New Science of Pleasure: Consumer Choice Behavior and the Measurement of Well-Being.

[36] Mishra, A.; Perry, J. (1999). Forward Contracting of Inputs: A farm-Level Analysis. Agricultural Economics Association of Georgia. Journal of Agribusiness, 17 (2).

[37] Asante, O. B.; Afari-Sefa,; V. Sarpong, D. B. (2011) Determinants of small scale farmeres decision to join farmer based organizations in Ghana, African Journal of Agricultural Research, 6 (10).

[38] Kumar Samanta. (2015) “A Study of Rural Electrification Infrastructure in India," IOSR J. Bus. Manag. $I V$, vol. 17, no. 2, pp. 2319-7668, 2015.

[39] Deichmann, F.; Shilpi,; R. Vakis, (2009) "Urban Proximity, Agricultural Potential and Rural Non-farm Employment: Evidence from Bangladesh," World Dev., vol. 37, no. 3, pp. 645-660, 2009.

[40] Echebiri, N., (2005). Characteristics and determinants of urban youth unemployment in Umuhia.

[41] Adepoju, A., (1986). Rural migration and Rural Development in Nigeria. Department of geography and social statistic, university of Ife.

[42] Adebayo, K., M.; Awotunde, P.A. Okuneye and U.V. Okonowo (2006), "Assessment of Secondary School Agricultural Education Programme in the Rural Areas of Imo State", Nigerian Journal of Rural Sociology. 